Acta Crystallographica Section C

Crystal Structure

Communications

ISSN 0108-2701

\section{Simple hydrogen-bonded chains in 2,2'-bipyridinium thiocyanate, hydrogen-bonded chains of rings in 2,2'-bipyridinium picrate and hydrogen-bonded sheets in 2,2'-bipyridinium hydrogensulfate}

\author{
Savaridasson Jose Kavitha, ${ }^{a}$ Krishnaswamy \\ Panchanatheswaran, $^{a}$ John N. Low, ${ }^{b}$ George Ferguson ${ }^{c}$ \\ and Christopher Glidewell ${ }^{\mathrm{C}}$.
}

\footnotetext{
${ }^{a}$ School of Chemistry, Bharathidasan University, Tiruchirappalli, Tamil Nadu 620 024, India, 'bepartment of Chemistry, University of Aberdeen, Meston Walk, Old Aberdeen AB24 3UE, Scotland, and ' School of Chemistry, University of St Andrews, Fife KY16 9ST, Scotland

Correspondence e-mail: cg@st-andrews.ac.uk
}

Received 7 February 2006

Accepted 10 February 2006

Online 11 March 2006

In 2,2'-bipyridinium thiocyanate, $\mathrm{C}_{10} \mathrm{H}_{9} \mathrm{~N}_{2}{ }^{+} \cdot \mathrm{NCS}^{-}$, the cations are disordered over two sets of sites with occupancies of 0.845 (2) and 0.155 (2). The ions are linked into simple chains by a combination of $\mathrm{N}-\mathrm{H} \cdots \mathrm{N}$ and $\mathrm{C}-\mathrm{H} \cdots \mathrm{N}$ hydrogen bonds, regardless of the orientation of the cation. In $2,2^{\prime}$ bipyridinium picrate, $\mathrm{C}_{10} \mathrm{H}_{9} \mathrm{~N}_{2}{ }^{+} \cdot \mathrm{C}_{6} \mathrm{H}_{2} \mathrm{~N}_{3} \mathrm{O}_{7}{ }^{-}$, the bond distances in the anion indicate a markedly non-classical electronic structure; the component ions are linked by a combination of six independent hydrogen bonds, viz. one of $\mathrm{N}-\mathrm{H} \cdots \mathrm{O}$ type and five of $\mathrm{C}-\mathrm{H} \cdots \mathrm{O}$ type, into a complex chain containing five distinct types of ring. The ions in 2,2'bipyridinium hydrogensulfate, $\mathrm{C}_{10} \mathrm{H}_{9} \mathrm{~N}_{2}{ }^{+} \cdot \mathrm{HSO}_{4}{ }^{-}$, are linked by a combination of five hydrogen bonds, viz. one each of $\mathrm{O}-$ $\mathrm{H} \cdots \mathrm{O}$ and $\mathrm{N}-\mathrm{H} \cdots \mathrm{O}$ types, and three of $\mathrm{C}-\mathrm{H} \cdots \mathrm{O}$ type, into complex sheets built from two one-dimensional substructures, each in the form of a complex chain of rings.

\section{Comment}

Two series of salts can be formed by 2,2'-bipyridine in which the cation is either monoprotonated, $\mathrm{C}_{10} \mathrm{H}_{9} \mathrm{~N}_{2}^{+}$(Kavitha et al., 2005), or diprotonated, $\mathrm{C}_{10} \mathrm{H}_{10} \mathrm{~N}_{2}{ }^{2+}$ (Nakatsu et al., 1972); the monocation can act as an acid, as a base or as a ligand. As part of a study of the coordination properties of this cation, we report here the molecular and supramolecular structures of three related organic salts, viz. 2,2'-bipyridinium thiocyanate, (I), 2,2'-bipyridinium picrate, (II), and 2,2'-bipyridinium hydrogensulfate, (III) (Figs. 1-3), and we briefly compare the structure of the latter with that of its close analogue 2,2'-bipyridinium perchlorate, (IV) (Kavitha et al., 2005).

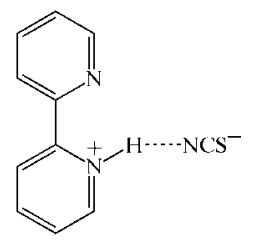

(I)<smiles></smiles>

(III)<smiles>O=[N+]([O-])c1cc([N+](=O)[O-])c([N+](=O)[O-])c([N+](=O)[O-])c1</smiles>

(II)<smiles></smiles>

(IV)<smiles>O=[N+]([O-])c1cc([N+](=O)[O-])c([O-])c([N+](=O)[O-])c1</smiles>

(II $a$ )<smiles>O=C1C(=O)C([N+](=O)[O-])C([N+](=O)[O-])C=C1[N+](=O)[O-]</smiles>

(IIb)<smiles>O=C1C([N+](=O)[O-])=CC([N+](=O)[O-])C(=O)C1[N+](=O)[O-]</smiles>

(IIc)
In (I), the cation is disordered over two sets of sites, with refined occupancies 0.845 (2) and 0.155 (2) (Fig. 1). Each orientation of the cation is nearly planar, but the $\mathrm{N}$ atoms are on opposite edges of the cation. Likewise, in each of (II) and (III), the cation has a nearly planar conformation, with the two $\mathrm{N}$ atoms on the same edge of the cation. In each compound, there is a short $\mathrm{N}-\mathrm{H} \cdots \mathrm{N}$ contact within the cation, but the $\mathrm{N}-\mathrm{H} \cdots \mathrm{N}$ angles are very small (Tables 2, 4 and 6). The internal angles at protonated atom N11 and unprotonated atom N21 (Tables 1, 3 and 5) show very marked differences in the expected sense (Domenicano \& Murray-Rust, 1979), with complementary differences in the internal angles at atoms $\mathrm{C} 12$ and C22. The two exocyclic angles at each of C12 and C22

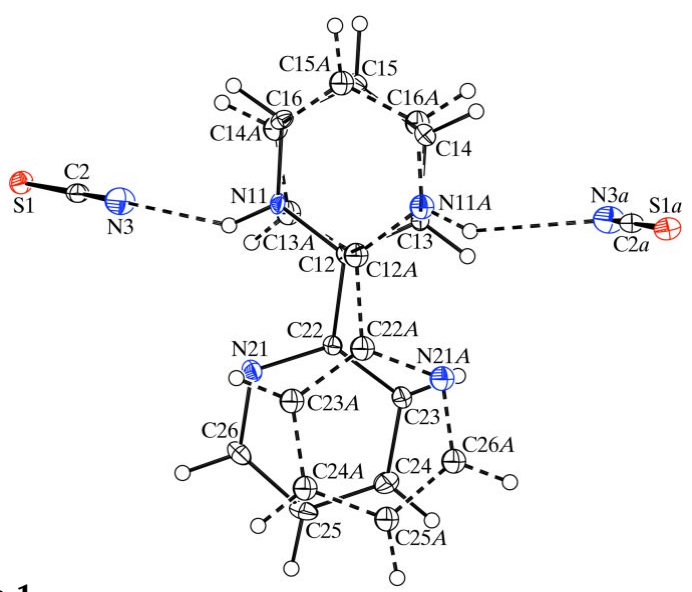

Figure 1

The independent components of (I), showing the cation disorder, the atom-labelling scheme and the two hydrogen bonds within the asymmetric unit. Displacement ellipsoids are drawn at the $30 \%$ probability level. 
differ by $c a 10^{\circ}$, always in the sense that the $\mathrm{N}-\mathrm{C}-\mathrm{C}$ angle is the smaller angle and the $\mathrm{C}-\mathrm{C}-\mathrm{C}$ angle is the larger angle (Tables 1, 3 and 5).

In the anion of (II), the nitro group at the 4-position is almost coplanar with the phenyl ring, but the nitro groups at the 2- and 6-positions are both twisted well out of the plane of the benzene ring, with dihedral angles between the nitro planes and the benzene plane of $46.3(2)$ and $20.5(2)^{\circ}$, respectively. The sense of these rotations is such that the anion retains approximate mirror symmetry. The bond distances within the ring indicate very marked deviation from regular hexagonal geometry, with the $\mathrm{C} 31-\mathrm{C} 32$ and $\mathrm{C} 36-\mathrm{C} 31$ bonds very much longer than the others, while the mean $\mathrm{C}-\mathrm{C}$ distance for the $\mathrm{C} 32-\mathrm{C} 33$ and $\mathrm{C} 35-\mathrm{C} 36$ bonds is somewhat less than the mean distance for the C33-C34 and C34-C35 bonds. In addition, the $\mathrm{C} 34-\mathrm{N} 34$ bond is shorter than the C $32-\mathrm{N} 32$ and C36-N36 bonds, while the C31-O31 bond, which is a single bond in the classical representation of the anion (II $a$ ), is extremely short for such a single bond but is comparable to the mean value (1.222 А; Allen et al. 1987) of $\mathrm{C}=\mathrm{O}$ bonds in benzoquinones. These observations, taken all together, indicate that ( $\mathrm{II} a$ ) is an inappropriate representation of the picrate anion here, but that the quinonoid form (IIb)

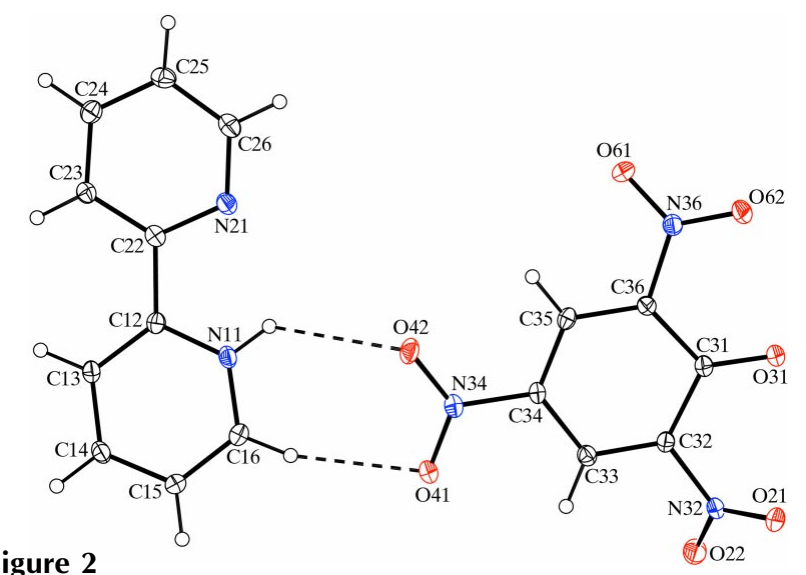

Figure 2
The independent components of (II), showing the atom-labelling scheme and the two hydrogen bonds within the asymmetric unit. Displacement ellipsoids are drawn at the $30 \%$ probability level.

Figure 3

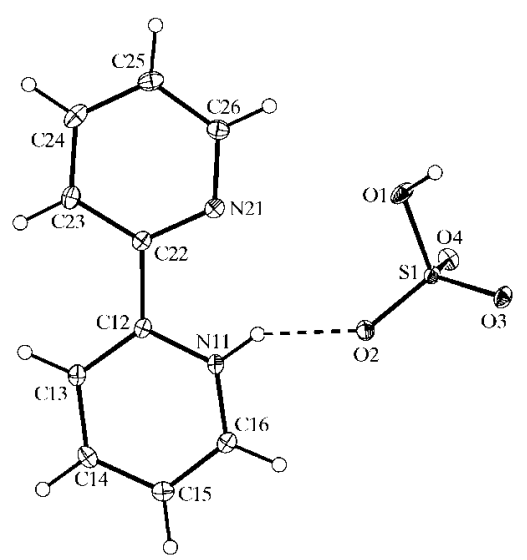

The independent components of (III), showing the atom-labelling scheme and the hydrogen bond within the asymmetric unit. Displacement ellipsoids are drawn at the $30 \%$ probability level. and the pentadienide form (IIc) are both important contributors to the overall molecular-electronic structure.

In the anion of (III), the $\mathrm{S}-\mathrm{O}(\mathrm{H})$ bond distance exceeds the other three $\mathrm{S}-\mathrm{O}$ distances by more than $0.1 \AA$, while the $\mathrm{O}-\mathrm{S}-\mathrm{O}$ angles involving protonated atom $\mathrm{O} 1$ are systematically less than the other $\mathrm{O}-\mathrm{S}-\mathrm{O}$ angles (Table 3 ).

Regardless of the orientation of the cation, the components in (I) are linked by one $\mathrm{N}-\mathrm{H} \cdots \mathrm{N}$ hydrogen bond and one $\mathrm{C}-\mathrm{H} \cdots \mathrm{N}$ hydrogen bond (Table 2 ), so forming a $C_{2}^{1}(6)$ chain running parallel to the [001] direction and generated by the $c$-glide plane at $y=0.25$ (Fig. 4). Two such chains run through each unit cell, but there are no direction-specific interactions between adjacent chains.

The component ions of (II) are linked into rather complex chains of rings, which may alternatively be described as perforated ribbons, by a combination of one $\mathrm{N}-\mathrm{H} \cdots \mathrm{O}$ hydrogen bond and no fewer than five $\mathrm{C}-\mathrm{H} \cdots \mathrm{O}$ hydrogen bonds (Table 4). Within the selected asymmetric unit (Fig. 2), the ions are linked by the co-operative action of the $\mathrm{N}-$ $\mathrm{H}$. . O hydrogen bond and one of the $\mathrm{C}-\mathrm{H} \cdots \mathrm{O}$ hydrogen bonds, generating a simple $R_{2}^{2}(7)$ (Bernstein et al., 1995) motif in which the acceptors are the two $\mathrm{O}$ atoms of a single nitro group. Three $\mathrm{C}-\mathrm{H}$. . O hydrogen bonds acting in concert link these ion-pair aggregates into chains of rings; atoms $\mathrm{C} 13$ and $\mathrm{C} 23$ in the cation at $(x, y, z)$ both act as hydrogen-bond donors to atom $\mathrm{O} 31$ in the anion at $(-1+x,-1+y, 1+z)$, while atom C14 in the cation at $(x, y, z)$ likewise acts as a donor to atom $\mathrm{O} 21$ in the anion at $(-1+x,-1+y, 1+z)$, so generating by translation a chain of rings running parallel to the [11 $\overline{1}]$ direction. The final $\mathrm{C}-\mathrm{H} \cdots \mathrm{O}$ hydrogen bond links antiparallel pairs of such chains to form the overall ribbon; atom C35 in the anion at $(x, y, z)$ acts as a hydrogen-bond donor to atom $\mathrm{O} 42$ in the anion at $(1-x, 1-y, 1-z)$, so forming a centrosymmetric $R_{2}^{2}(10)$ anion dimer centred at $\left(\frac{1}{2}, \frac{1}{2}, \frac{1}{2}\right)$.

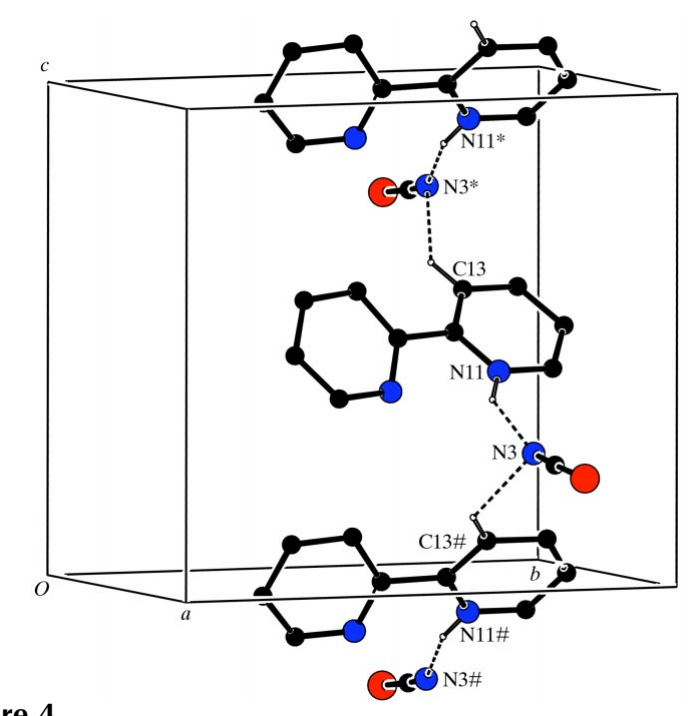

Figure 4

Part of the crystal structure of (I), showing the formation of a $C_{2}^{1}(6)$ chain along [001]. For the sake of clarity, only the major orientation of the cation is shown and $\mathrm{H}$ atoms not involved in the motif shown have been omitted. Atoms marked with an asterisk $(*)$ or a hash $(\#)$ are at the symmetry positions $\left(\frac{1}{2}-x, y, \frac{1}{2}+z\right)$ and $\left(\frac{1}{2}-x, y,-\frac{1}{2}+z\right)$, respectively. 
Propagation by translation and inversion of all these hydrogen bonds then generates a complex chain of rings along [111] containing a central strip of alternating edge-fused $R_{2}^{2}(10)$ and $R_{6}^{4}(22)$ rings, with the $R_{2}^{2}(10)$ rings centred at $\left(n+\frac{1}{2}, n+\frac{1}{2}\right.$, $\left.-n+\frac{1}{2}\right)\left(n=\right.$ zero or integer) and the $R_{6}^{4}(22)$ rings centred at $(n, n,-n)(n=$ zero or integer). This central array of centrosymmetric rings is flanked on each edge of the ribbon by strings of alternating single $R_{2}^{2}(7)$ rings, which lie within the asymmetric unit, and the edge-fused $R_{2}^{1}(7)$ and $R_{2}^{2}(8)$ rings, which are generated by translation. There are thus five distinct types of ring within this ribbon structure (Fig. 5), but there are no direction-specific interactions between adjacent ribbons.

The components of (III) are linked into complex sheets by a combination of $\mathrm{O}-\mathrm{H} \cdots \mathrm{O}, \mathrm{N}-\mathrm{H} \cdots \mathrm{O}$ and $\mathrm{C}-\mathrm{H} \cdots \mathrm{O}$ hydrogen bonds (Table 6), but the formation of this sheet structure is readily analysed in terms of two one-dimensional substructures. The $\mathrm{N}-\mathrm{H} \cdots \mathrm{O}$ hydrogen bond links the two components within the selected asymmetric unit (Fig. 3), while the $\mathrm{O}-\mathrm{H} \cdots \mathrm{O}$ hydrogen bond and three independent $\mathrm{C}-$ $\mathrm{H} \cdots \mathrm{O}$ hydrogen bonds link these ion-pair aggregates.
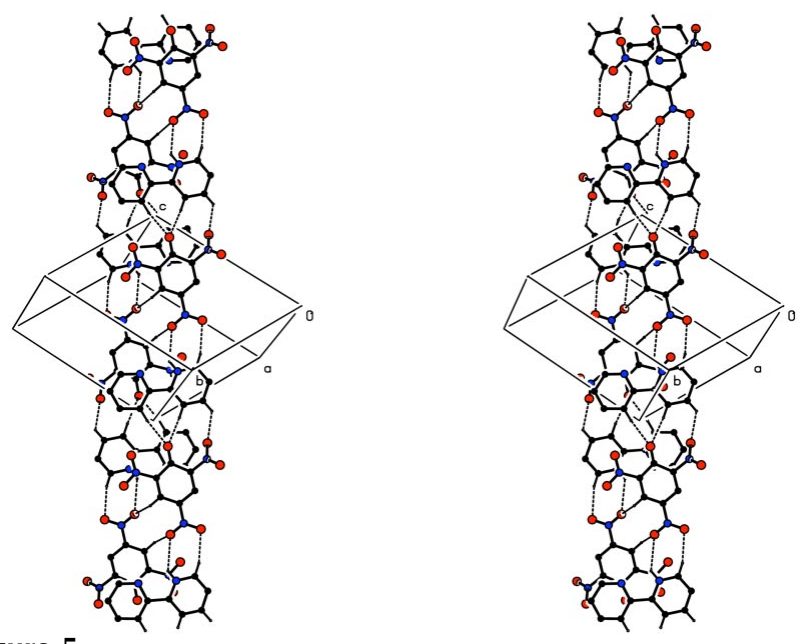

Figure 5

A stereoview of part of the crystal structure of (II), showing the formation of a hydrogen-bonded [111] chain containing five different types of ring. For the sake of clarity, $\mathrm{H}$ atoms not involved in the hydrogen bonds shown have been omitted.

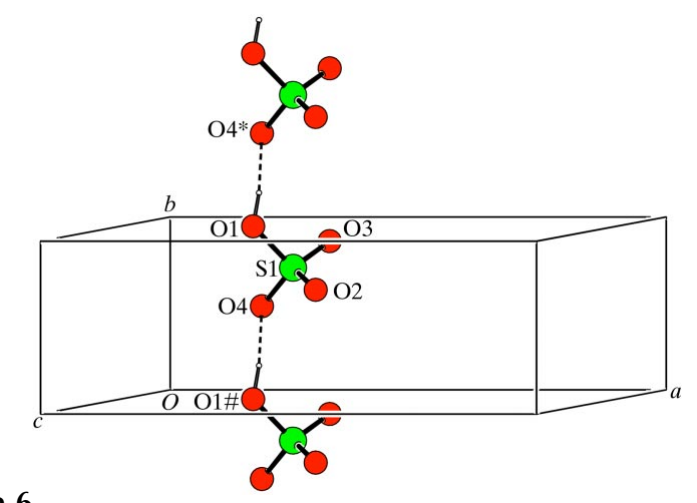

Figure 6

Part of the crystal structure of (III), showing the formation of a hydrogenbonded $C(4)$ chain of anions along [010]. Atoms marked with an asterisk $(*)$ or a hash (\#) are at the symmetry positions $(x, 1+y, z)$ and $(x,-1+y$, $z)$, respectively.
A very simple substructure is generated by the anions alone. Atom $\mathrm{O} 1$ in the anion at $(x, y, z)$ acts as a hydrogen-bond donor to atom $\mathrm{O} 4$ in the anion at $(x, 1+y, z)$, so generating by translation a $C(4)$ chain running parallel to the [010] direction (Fig. 6). This [010] chain is reinforced by one of the $\mathrm{C}-\mathrm{H} \cdots \mathrm{O}$ hydrogen bonds. Atom $\mathrm{C} 15$ in the cation at $(x, y, z)$ acts as a hydrogen-bond donor to atom $\mathrm{O} 3$ in the anion at $\left(1-x,-\frac{3}{2}+y\right.$, $\left.\frac{1}{2}-z\right)$, while atom $\mathrm{C} 15$ at $\left(1-x,-\frac{3}{2}+y, \frac{1}{2}-z\right)$ in turn acts as a donor to atom $\mathrm{O} 3$ at $(x,-3+y, z)$, so producing a chain of edge-fused $R_{6}^{6}(24)$ rings generated by the $2_{1}$ screw axis along $\left(\frac{1}{2}, y, \frac{1}{4}\right)$ (Fig. 7).

A second one-dimensional substructure is generated by the concerted action of two $\mathrm{C}-\mathrm{H} \cdots \mathrm{O}$ hydrogen bonds. Atoms $\mathrm{C} 13$ and $\mathrm{C} 14$ in the cation at $(x, y, z)$ act as hydrogen-bond donors, respectively, to atoms $\mathrm{O} 4$ and $\mathrm{O} 3$, both in the anion at $\left(x, \frac{1}{2}-y, \frac{1}{2}+z\right)$. In combination with the $\mathrm{N}-\mathrm{H} \cdots \mathrm{O}$ hydrogen bond within the asymmetric unit, these two $\mathrm{C}-\mathrm{H} \cdots \mathrm{O}$ hydrogen bonds form a $C_{2}^{2}(8) C_{2}^{2}(9)\left[R_{2}^{2}(7)\right]$ chain of rings running parallel to the [001] direction and generated by the $c$-glide plane at $y=0.25$ (Fig. 8). The combination of the [010] and [001] substructures (Figs. 7 and 8) generates a complex
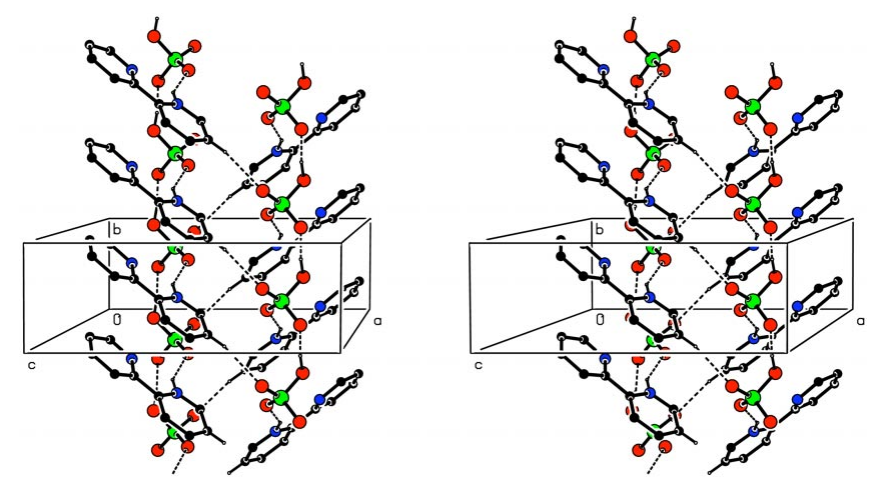

Figure 7

A stereoview of part of the crystal structure of (III), showing the formation of a hydrogen-bonded chain of edge-fused $R_{6}^{6}(24)$ rings along [010]. For the sake of clarity, $\mathrm{H}$ atoms not involved in the hydrogen bonds shown have been omitted.
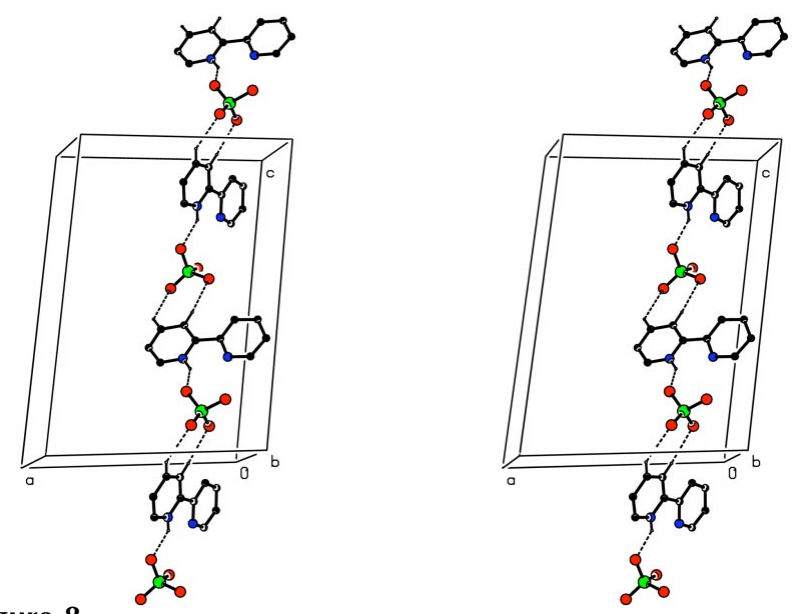

Figure 8

A stereoview of part of the crystal structure of (III), showing the formation of a hydrogen-bonded $C_{2}^{2}(8) C_{2}^{2}(9)\left[R_{2}^{2}(7)\right]$ chain of rings along [001]. For the sake of clarity, $\mathrm{H}$ atoms not involved in the hydrogen bonds shown have been omitted. 
(100) sheet, but there are no direction-specific interactions between adjacent sheets.

Although (III) and (IV) have similar compositions, they crystallize with very different unit cells in different space groups, viz. $P 2_{1} / c$ for (III) and $P c$ for (IV) (Kavitha et al., 2005). Despite this difference, they form a common substructural motif in the form of the $C_{2}^{2}(8) C_{2}^{2}(9)\left[R_{2}^{2}(7)\right]$ chain of rings (Fig. $6)$, generated by the action of a glide plane in (III) but by translation in (IV). There can be no anion-chain substructure in (IV), but all four $\mathrm{O}$ atoms of the perchlorate anion act as acceptors in hydrogen bonds, and the overall supramolecular structure takes the form of a rather complex sheet.

\section{Experimental}

For the synthesis of $(\mathrm{I})$, a solution in methanol $(50 \mathrm{ml})$ of $2,2^{\prime}$-bipyridinium chloride $(0.5 \mathrm{~g})$ (itself prepared by the reaction between concentrated hydrochloric acid and 2,2'-bipyridine in a 1:1 molar ratio in methanol) was added to ammonium thiocyanate $(0.23 \mathrm{~g})$ and the resulting mixture was heated on a water bath for $30 \mathrm{~min}$. The mixture was cooled to ambient temperature, and subsequent slow evaporation of the solvent gave crystals of (I) (m.p. $401 \mathrm{~K}$ ) suitable for single-crystal X-ray diffraction. For the synthesis of (II), a solution of picric acid $(0.44 \mathrm{~g})$ in methanol $(50 \mathrm{ml})$ was added to a solution of $2,2^{\prime}$-bipyridine $(0.3 \mathrm{~g})$ in methanol $(50 \mathrm{ml})$; this mixture was then warmed on a water bath for $15 \mathrm{~min}$. After cooling of the solution to ambient temperature, slow evaporation of the solvent yielded crystals of (II) (m.p. $398 \mathrm{~K}$ ) suitable for single-crystal X-ray diffraction. Compound (III) (m.p. $418 \mathrm{~K}$ ) was prepared in a similar manner using $0.5 \mathrm{~g}$ of $2,2^{\prime}$-bipyridine and $0.36 \mathrm{ml}$ of concentrated sulfuric acid.

\section{Compound (I)}

Crystal data
$\mathrm{C}_{10} \mathrm{H}_{9} \mathrm{~N}_{2}{ }^{+} \cdot \mathrm{NCS}^{-}$
$M_{r}=215.27$
Orthorhombic, $P_{c a 2_{1}}$
$a=8.0954(2) \AA$
$b=11.7686(6) \AA$
$c=11.0026(6) \AA$
$V=1048.23(8) \AA^{3}$
$Z=4$
$D_{x}=1.364 \mathrm{Mg} \mathrm{m}^{-3}$

\author{
Mo $K \alpha$ radiation \\ Cell parameters from 2311 \\ reflections \\ $\theta=3.6-27.5^{\circ}$ \\ $\mu=0.28 \mathrm{~mm}^{-1}$ \\ $T=120(2) \mathrm{K}$ \\ Plate, colourless \\ $0.40 \times 0.40 \times 0.04 \mathrm{~mm}$
}

\section{Data collection}

Bruker KappaCCD diffractometer $\varphi$ and $\omega$ scans

Absorption correction: multi-scan

(SADABS; Sheldrick, 2003)

$T_{\min }=0.898, T_{\max }=0.989$

7990 measured reflections

2311 independent reflections

\author{
2145 reflections with $I>2 \sigma(I)$ \\ $R_{\text {int }}=0.033$ \\ $\theta_{\text {max }}=27.5^{\circ}$ \\ $h=-10 \rightarrow 8$ \\ $k=-12 \rightarrow 15$ \\ $l=-14 \rightarrow 14$
}

Table 1

Selected geometric parameters $\left(\AA{ }^{\circ}\right)$ for (I).

\begin{tabular}{lllr}
\hline $\mathrm{S} 1-\mathrm{C} 2$ & $1.6383(16)$ & $\mathrm{C} 2-\mathrm{N} 3$ & $1.166(2)$ \\
$\mathrm{C} 16-\mathrm{N} 11-\mathrm{C} 12$ & $122.5(3)$ & $\mathrm{C} 26-\mathrm{N} 21-\mathrm{C} 22$ & $116.25(18)$ \\
$\mathrm{N} 11-\mathrm{C} 12-\mathrm{C} 13$ & $118.4(2)$ & $\mathrm{N} 21-\mathrm{C} 22-\mathrm{C} 23$ & $124.37(19)$ \\
$\mathrm{N} 11-\mathrm{C} 12-\mathrm{C} 22$ & $117.2(2)$ & $\mathrm{N} 21-\mathrm{C} 22-\mathrm{C} 12$ & $115.08(19)$ \\
$\mathrm{C} 13-\mathrm{C} 12-\mathrm{C} 22$ & $124.4(2)$ & $\mathrm{C} 23-\mathrm{C} 22-\mathrm{C} 12$ & $120.54(19)$ \\
$\mathrm{N} 3-\mathrm{C} 2-\mathrm{S} 1$ & $177.56(19)$ & & \\
& & & \\
$\mathrm{N} 11-\mathrm{C} 12-\mathrm{C} 22-\mathrm{N} 21$ & $-18.9(3)$ & $\mathrm{N} 11 A-\mathrm{C} 12 A-\mathrm{C} 22 A-\mathrm{N} 21 A-19(3)$ \\
\hline
\end{tabular}

Table 2

Hydrogen-bond geometry $\left(\AA,^{\circ}\right)$ for (I).

\begin{tabular}{lllll}
\hline$D-\mathrm{H} \cdots A$ & $D-\mathrm{H}$ & $\mathrm{H} \cdots A$ & $D \cdots A$ & $D-\mathrm{H} \cdots A$ \\
\hline $\mathrm{N} 11-\mathrm{H} 11 \cdots \mathrm{N} 3$ & 0.88 & 2.03 & $2.788(4)$ & 144 \\
$\mathrm{~N} 11-\mathrm{H} 11 \cdots \mathrm{N} 21$ & 0.88 & 2.33 & $2.693(4)$ & 104 \\
$\mathrm{~N} 11 A-\mathrm{H} 11 A \cdots \mathrm{N} 3^{\mathrm{i}}$ & 0.88 & 2.34 & $3.12(2)$ & 148 \\
$\mathrm{~N} 11 A-\mathrm{H} 11 A \cdots \mathrm{N} 21 A$ & 0.88 & 2.42 & $2.75(2)$ & 103 \\
$\mathrm{C} 13-\mathrm{H} 13 \cdots \mathrm{N} 3^{\mathrm{i}}$ & 0.95 & 2.53 & $3.217(4)$ & 129 \\
$\mathrm{C} 13 A-\mathrm{H} 13 A \cdots \mathrm{N} 3$ & 0.95 & 2.27 & $2.93(3)$ & 126 \\
\hline
\end{tabular}

Symmetry code: (i) $-x+\frac{1}{2}, y, z+\frac{1}{2}$.

\section{Refinement}

Refinement on $F^{2}$

$R\left[F^{2}>2 \sigma\left(F^{2}\right)\right]=0.031$

$w R\left(F^{2}\right)=0.077$

$S=1.05$

2311 reflections

174 parameters

$\mathrm{H}$-atom parameters constrained

\section{Compound (II)}

Crystal data

$\mathrm{C}_{10} \mathrm{H}_{9} \mathrm{~N}_{2}^{+} \cdot \mathrm{C}_{6} \mathrm{H}_{2} \mathrm{~N}_{3} \mathrm{O}_{7}{ }^{-}$
$M_{r}=385.30$
Triclinic, $P \overline{1}$
$a=7.4139(5) \AA$
$b=9.3768(6) \AA$
$c=12.3694(5) \AA$
$\alpha=71.681(3)^{\circ}$
$\beta=75.722(3)^{\circ}$
$\gamma=77.391(3)^{\circ}$
$V=781.79(8) \AA^{3}$

Data collection

Nonius KappaCCD diffractometer $\varphi$ and $\omega$ scans

Absorption correction: multi-scan (SADABS; Sheldrick, 2003)

$T_{\min }=0.975, T_{\max }=0.996$

17473 measured reflections

3598 independent reflections

Refinement

Refinement on $F^{2}$

$R\left[F^{2}>2 \sigma\left(F^{2}\right)\right]=0.060$

$w R\left(F^{2}\right)=0.122$

$S=1.04$

3598 reflections

253 parameters

$\mathrm{H}$-atom parameters constrained

Table 3

Selected geometric parameters $\left(\AA,^{\circ}\right)$ for (II).

\begin{tabular}{llll}
\hline $\mathrm{C} 31-\mathrm{C} 32$ & $1.460(3)$ & $\mathrm{C} 36-\mathrm{C} 31$ & $1.452(3)$ \\
$\mathrm{C} 32-\mathrm{C} 33$ & $1.359(3)$ & $\mathrm{C} 31-\mathrm{O} 31$ & $1.243(2)$ \\
$\mathrm{C} 33-\mathrm{C} 34$ & $1.401(3)$ & $\mathrm{C} 32-\mathrm{N} 32$ & $1.454(3)$ \\
$\mathrm{C} 34-\mathrm{C} 35$ & $1.376(3)$ & $\mathrm{C} 34-\mathrm{N} 34$ & $1.436(2)$ \\
$\mathrm{C} 35-\mathrm{C} 36$ & $1.376(3)$ & $\mathrm{C} 36-\mathrm{N} 36$ & $1.454(3)$
\end{tabular}

$\begin{array}{lrll}\mathrm{C} 16-\mathrm{N} 11-\mathrm{C} 12 & 123.86(18) & \mathrm{C} 26-\mathrm{N} 21-\mathrm{C} 22 & 116.95(18) \\ \mathrm{N} 11-\mathrm{C} 12-\mathrm{C} 13 & 117.78(19) & \mathrm{N} 21-\mathrm{C} 22-\mathrm{C} 23 & 123.67(19) \\ \mathrm{N} 11-\mathrm{C} 12-\mathrm{C} 22 & 115.64(17) & \mathrm{N} 21-\mathrm{C} 22-\mathrm{C} 12 & 113.89(18) \\ \mathrm{C} 13-\mathrm{C} 12-\mathrm{C} 22 & 126.53(19) & \mathrm{C} 23-\mathrm{C} 22-\mathrm{C} 12 & 122.40(18) \\ & & & \\ & & & \\ \mathrm{N} 11-\mathrm{C} 12-\mathrm{C} 22-\mathrm{N} 21 & -1.1(3) & \mathrm{C} 33-\mathrm{C} 34-\mathrm{N} 34-\mathrm{O} 41 & -1.8(3) \\ \mathrm{C} 31-\mathrm{C} 32-\mathrm{N} 32-\mathrm{O} 21 & 47.5(3) & \mathrm{C} 31-\mathrm{C} 36-\mathrm{N} 36-\mathrm{O} 61 & 158.46(18)\end{array}$

\author{
$Z=2$ \\ $D_{x}=1.637 \mathrm{Mg} \mathrm{m}^{-3}$ \\ Mo $K \alpha$ radiation \\ Cell parameters from 3598 \\ reflections \\ $\theta=3.2-27.6^{\circ}$ \\ $\mu=0.13 \mathrm{~mm}^{-1}$ \\ $T=120(2) \mathrm{K}$ \\ Lath, yellow \\ $0.12 \times 0.09 \times 0.03 \mathrm{~mm}$
}

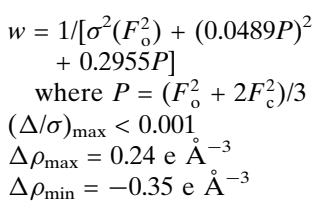


Table 4

Hydrogen-bond geometry $\left(\AA{ }^{\circ}{ }^{\circ}\right)$ for (II).

\begin{tabular}{lllll}
\hline$D-\mathrm{H} \cdots A$ & $D-\mathrm{H}$ & $\mathrm{H} \cdots A$ & $D \cdots A$ & $D-\mathrm{H} \cdots A$ \\
\hline $\mathrm{N} 11-\mathrm{H} 11 \cdots \mathrm{N} 21$ & 0.88 & 2.21 & $2.613(3)$ & 107 \\
$\mathrm{~N} 11-\mathrm{H} 11 \cdots \mathrm{O} 42$ & 0.88 & 2.55 & $3.204(2)$ & 131 \\
$\mathrm{C} 13-\mathrm{H} 13 \cdots \mathrm{O} 31^{\mathrm{ii}}$ & 0.95 & 2.37 & $3.279(2)$ & 160 \\
$\mathrm{C} 14-\mathrm{H} 14 \cdots \mathrm{O} 21^{\mathrm{ii}}$ & 0.95 & 2.38 & $3.028(2)$ & 125 \\
$\mathrm{C} 16-\mathrm{H} 16 \cdots \mathrm{O} 41$ & 0.95 & 2.36 & $3.284(3)$ & 164 \\
$\mathrm{C} 23-\mathrm{H} 23 \cdots \mathrm{O} 31^{\mathrm{ii}}$ & 0.95 & 2.42 & $3.325(2)$ & 159 \\
$\mathrm{C} 35-\mathrm{H} 35 \cdots \mathrm{O} 42^{\mathrm{iii}}$ & 0.95 & 2.48 & $3.204(3)$ & 133 \\
\hline
\end{tabular}

Symmetry codes: (ii) $x-1, y-1, z+1$; (iii) $-x+1,-y+1,-z+1$.

\section{Compound (III)}

Crystal data

$\mathrm{C}_{10} \mathrm{H}_{9} \mathrm{~N}_{2}{ }^{+} \cdot \mathrm{HSO}_{4}{ }^{-}$
$M_{r}=254.26$
Monoclinic, $P 2_{1} / c$
$a=12.8274(4) \AA$
$b=4.4774(2) \AA$
$c=18.2844(5) \AA$
$\beta=100.568(2)^{\circ}$
$V=1032.32(6) \AA^{3}$
$Z=4$

$D_{x}=1.636 \mathrm{Mg} \mathrm{m}^{-3}$

Mo $K \alpha$ radiation

Cell parameters from 2373 reflections

$\theta=3.6-27.5^{\circ}$

$\mu=0.32 \mathrm{~mm}^{-1}$

$T=120(2) \mathrm{K}$

Plate, pink

$0.42 \times 0.16 \times 0.06 \mathrm{~mm}$

\section{Data collection}

Nonius KappaCCD diffractometer $\varphi$ and $\omega$ scans

Absorption correction: multi-scan (SADABS; Sheldrick, 2003)

$T_{\min }=0.878, T_{\max }=0.981$

19500 measured reflections

2373 independent reflections

$$
\begin{aligned}
& 2052 \text { reflections with } I>2 \sigma(I) \\
& R_{\text {int }}=0.043 \\
& \theta_{\max }=27.5^{\circ} \\
& h=-16 \rightarrow 16 \\
& k=-5 \rightarrow 5 \\
& l=-23 \rightarrow 23
\end{aligned}
$$

\section{Refinement}

Refinement on $F^{2}$

$R\left[F^{2}>2 \sigma\left(F^{2}\right)\right]=0.044$

$w R\left(F^{2}\right)=0.122$

$S=1.26$

2373 reflections

154 parameters

$\mathrm{H}$-atom parameters constrained

$$
\begin{gathered}
w=1 /\left[\sigma^{2}\left(F_{\mathrm{o}}^{2}\right)+(0.0285 P)^{2}\right. \\
+2.1787 P] \\
\text { where } P=\left(F_{\mathrm{o}}^{2}+2 F_{\mathrm{c}}^{2}\right) / 3 \\
(\Delta / \sigma)_{\max }<0.001 \\
\Delta \rho_{\max }=0.39 \AA^{-3} \AA^{-3} \\
\Delta \rho_{\min }=-0.45 \mathrm{e} \AA^{-3}
\end{gathered}
$$

Table 5

Selected geometric parameters $\left(\AA{ }^{\circ},{ }^{\circ}\right)$ for (III).

\begin{tabular}{llll}
\hline $\mathrm{S} 1-\mathrm{O} 1$ & $1.5699(19)$ & $\mathrm{S} 1-\mathrm{O} 4$ & $1.4672(19)$ \\
$\mathrm{S} 1-\mathrm{O} 2$ & $1.4526(19)$ & & \\
& & & \\
$\mathrm{C} 16-\mathrm{N} 11-\mathrm{C} 12$ & $123.5(2)$ & $\mathrm{C} 26-\mathrm{N} 21-\mathrm{C} 22$ & $117.7(2)$ \\
$\mathrm{N} 11-\mathrm{C} 12-\mathrm{C} 13$ & $118.0(2)$ & $\mathrm{N} 21-\mathrm{C} 22-\mathrm{C} 23$ & $123.3(2)$ \\
$\mathrm{N} 11-\mathrm{C} 12-\mathrm{C} 22$ & $115.8(2)$ & $\mathrm{N} 21-\mathrm{C} 22-\mathrm{C} 12$ & $114.4(2)$ \\
$\mathrm{C} 13-\mathrm{C} 12-\mathrm{C} 22$ & $126.2(2)$ & $\mathrm{C} 23-\mathrm{C} 22-\mathrm{C} 12$ & $122.2(2)$ \\
$\mathrm{O} 1-\mathrm{S} 1-\mathrm{O} 2$ & $105.72(11)$ & $\mathrm{O} 2-\mathrm{S} 1-\mathrm{O} 3$ & $113.97(11)$ \\
$\mathrm{O} 1-\mathrm{S} 1-\mathrm{O} 3$ & $106.92(11)$ & $\mathrm{O} 2-\mathrm{S} 1-\mathrm{O} 4$ & $111.05(11)$ \\
$\mathrm{O} 1-\mathrm{S} 1-\mathrm{O} 4$ & $105.05(11)$ & $\mathrm{O} 3-\mathrm{S} 1-\mathrm{O} 4$ & $113.33(11)$
\end{tabular}

$\mathrm{N} 11-\mathrm{C} 12-\mathrm{C} 22-\mathrm{N} 21 \quad 5.3(3)$

For (I), the systematic absences permitted $P c a 2_{1}$ or $P c a m(=P b c m$, No. 57) as possible space groups; $P c a 2_{1}$ was selected and confirmed by the structure analysis. Crystals of (II) are triclinic; the space group $P \overline{1}$
Table 6

Hydrogen-bond geometry $\left(\AA,^{\circ}\right)$ for (III).

\begin{tabular}{lllll}
\hline$D-\mathrm{H} \cdots A$ & $D-\mathrm{H}$ & $\mathrm{H} \cdots A$ & $D \cdots A$ & $D-\mathrm{H} \cdots A$ \\
\hline $\mathrm{O} 1-\mathrm{H} 1 \cdots \mathrm{O}^{\text {iv }}$ & 0.94 & 1.70 & $2.640(3)$ & 173 \\
$\mathrm{~N} 11-\mathrm{H} 11 \cdots \mathrm{O} 2$ & 0.88 & 1.98 & $2.752(3)$ & 146 \\
$\mathrm{~N} 11-\mathrm{H} 11 \cdots \mathrm{N} 21$ & 0.88 & 2.23 & $2.625(3)$ & 107 \\
$\mathrm{C} 13-\mathrm{H} 13 \cdots \mathrm{O}^{\mathrm{v}}$ & 0.95 & 2.44 & $3.389(3)$ & 173 \\
$\mathrm{C} 14-\mathrm{H} 14 \cdots \mathrm{O}^{\mathrm{v}}$ & 0.95 & 2.48 & $3.156(3)$ & 129 \\
$\mathrm{C}^{\mathrm{v}} \mathrm{H} 15 \cdots \mathrm{O}^{\text {vi }}$ & 0.95 & 2.52 & $3.433(3)$ & 161 \\
\hline
\end{tabular}

Symmetry codes: (iv) $x, y+1, z$; (v) $x,-y+\frac{1}{2}, z+\frac{1}{2}$; (vi) $-x+1, y-\frac{3}{2},-z+\frac{1}{2}$.

was selected and confirmed by the subsequent structure analysis. For (III), the space group $P 2_{1} / c$ was uniquely assigned from the systematic absences. All $\mathrm{H}$ atoms were located in difference maps and then treated as riding atoms with $\mathrm{C}-\mathrm{H}$ distances of $0.95 \AA, \mathrm{N}-\mathrm{H}$ distances of $0.88 \AA$ and an $\mathrm{O}-\mathrm{H}$ distance of $0.94 \AA$, and with $U_{\text {iso }}(\mathrm{H})$ values of $1.2 U_{\mathrm{eq}}(\mathrm{C}, \mathrm{N})$ or $1.5 U_{\mathrm{eq}}(\mathrm{O})$. For $(\mathrm{I})$, the refined occupancies of the major and minor orientations of the cation were 0.845 (2) and 0.155 (2), respectively; in addition, the crystals of (I) were found to exhibit inversion twinning with twin fractions 0.57 (7) and 0.43 (7).

For all compounds, data collection: COLLECT (Hooft, 1999); cell refinement: DENZO (Otwinowski \& Minor, 1997) and COLLECT; data reduction: $D E N Z O$ and COLLECT; program(s) used to solve structure: OSCAIL (McArdle, 2003) and SHELXS97 (Sheldrick, 1997); program(s) used to refine structure: OSCAIL and SHELXL97 (Sheldrick, 1997); molecular graphics: PLATON (Spek, 2003); software used to prepare material for publication: SHELXL97 and PRPKAPPA (Ferguson, 1999).

X-ray data were collected at the EPSRC X-ray Crystallographic Service, University of Southampton, England. The authors thank the staff for all their help and advice.

Supplementary data for this paper are available from the IUCr electronic archives (Reference: SK1900). Services for accessing these data are described at the back of the journal.

\section{References}

Allen, F. H., Kennard, O., Watson, D. G., Brammer, L., Orpen, A. G. \& Taylor, R. (1987). J. Chem. Soc. Perkin Trans. 2, pp. S1-19.

Bernstein, J., Davis, R. E., Shimoni, L. \& Chang, N.-L. (1995). Angew. Chem. Int. Ed. Engl. 34, 1555-1573.

Domenicano, A. \& Murray-Rust, P. (1979). Tetrahedron Lett. pp. 2283-2386.

Ferguson, G. (1999). PRPKAPPA. University of Guelph, Canada.

Flack, H. D. (1983). Acta Cryst. A39, 876-881.

Hooft, R. W. W. (1999). COLLECT. Nonius BV, Delft, The Netherlands.

Kavitha, S. J., Panchanatheswaran, K., Low, J. N. \& Glidewell, C. (2005). Acta Cryst. C61, o473-0474.

McArdle, P. (2003). OSCAIL for Windows. Version 10. Crystallography Centre, Chemistry Department, NUI Galway, Ireland.

Nakatsu, K., Yoshida, H., Matsui, M., Koda, S. \& Ooi, S. (1972). Acta Cryst. A28, S24.

Otwinowski, Z. \& Minor, W. (1997). Methods in Enzymology, Vol. 276, Macromolecular Crystallography, Part A, edited by C. W. Carter Jr \& R. M. Sweet, pp. 307-326. New York: Academic Press.

Sheldrick, G. M. (1997). SHELXS97 and SHELXL97. University of Göttingen, Germany.

Sheldrick, G. M. (2003). SADABS. Version 2.10. University of Göttingen, Germany.

Spek, A. L. (2003). J. Appl. Cryst. 36, 7-13. 